\title{
Linking Entrepreneurial Orientation with Organizational Performance of Small and Medium Sized Enterprises: A Conceptual Approach
}

\author{
Jawad Hussain $^{1}$, Kamariah Ismail ${ }^{1} \&$ Ch. Shoaib Akhtar ${ }^{1}$ \\ ${ }^{1}$ Department of Management, Faculty of Management, Universiti Teknologi Malaysia, Malaysia \\ Correspondence: Kamariah Ismail, Department of Management, Faculty of Management, Universiti Teknologi \\ Malaysia, Johor Bahru, Johor, Malaysia. E-mail: m-maria@utm.my
}

Received: August 4, $2014 \quad$ Accepted: January 8,2015 Online Published: March 16, 2015
doi:10.5539/ass.v11n7p1
URL: http://dx.doi.org/10.5539/ass.v11n7p1

\begin{abstract}
Research examining the relationship between entrepreneurial orientation (EO) and business performance has recently received considerable attention in the marketing and entrepreneurship literature. Empirical studies on the determinants of firm performance have shown that the entrepreneurial orientation of a firm has significant positive influence on the firm performance. However, less attention has been paid to this relationship in the context of SMEs. This study therefore contributes to the existing literature by examining this relationship in SMEs context. The current study suggests that the owners/ managers of SMEs should adopt the EO mindset in order to attain sustainable competitive advantage and superior performance. The current study provides insights to researchers, practitioners, owners and managers on the importance of the dimensions of entrepreneurial orientation.
\end{abstract}

Keywords: autonomy, competitive aggressiveness, entrepreneurial orientation, innovativeness, proactiveness, risk taking

\section{Introduction}

The management research has mainly focused on the entrepreneurial orientation (Ireland and Webb 2007) that explains how entrepreneurship is put into practice. Entrepreneurial orientation is considered as a managerial attitude oriented toward the strategy-making processes that provides organizations with a basis for entrepreneurial decisions and actions (Lumpkin \& Dess, 1996; Richard, Barnett, Dwyer, \& Chadwick, 2004; Alegre \& Chiva, 2013).

With increase in the complexity of global economy, the significance of entrepreneurial activities has also increased for attaining the organizational sustainability and competitive advantage (Wiklund \& Shepherd, 2005). The globalization phenomenon has exerted huge pressure on the organizations, especially on the small and medium sized enterprises (SMEs). The scope of preferences of the customers across the globe has also become widened. These factors have placed the organizations at a stage where they feel it difficult to cope with the pressure exerted by the outside forces. The organizations failing to manage this pressure are out performed by the competitors (Kraus, Rigtering, Hughes, \& Hosman, 2012). SMEs are required to develop an entrepreneurial culture to better understand the threats and opportunities in the market and to ensure their sustainability (Krueger, 2000). The situation of economic turmoil increased the prevalent risk and uncertainty in the business world that in turn has increased the existing pressure on the firms. This situation demands to develop a quick response mechanism at the firm level in order to cope with the changing environment (Chattopadhyay, Glick, \& Huber, 2001; Lin \& Carley, 2001).

Entrepreneurship has been an area of interest for many researchers for the last two decades. However, the researchers could not develop any consensus regarding the definition of the entrepreneurship. Different researchers have discussed the term "entrepreneurship" from different perspectives like creation of enterprise, creation of wealth, creation of innovation, creation of employment, creation of change, creation of growth and value (Morris, Kuratko, \& Covin, 2008; Williams, Round, \& Rodgers, 2010; Kraus et al., 2012). Perhaps the most comprehensive definition has been given by the Morris et al (2008). They defined it as "entrepreneurship is a process of creating value by bringing together a unique package of resources to exploit an opportunity". According to Sexton and Kasarda (1992), Entrepreneurship refers to individual opportunistic activity that creates value and bears risk, and is strongly associated with innovation. Entrepreneurship at firm level stems from the 
entrepreneurial venture's orientation towards identifying market opportunities that competitors have not yet recognized or that are under-exploited, and creating a unique set of resources to exploit them (Hughes \& Morgan, 2007). Entrepreneurial orientation (EO) refers to a strategy that accelerate the speed of renaissance and performance of the organization (Zahra \& Garvis, 2000). EO is strategic in nature. This strategic nature of EO includes the organizational renewal, success in international market, learning the new ways to increase the revenue stream, increasing the effectiveness, bringing innovative products or services, and efficient use of organizational resources to attain sustainable competitive advantage and superior performance (Birkinshaw, 1997; Covin, Green, \& Slevin, 2006; Kraus et al., 2012).

\section{Literature Review}

\subsection{Entrepreneurial Orientation}

The entrepreneurial orientation construct was developed by Miller (1983). This construct focused the tendency of organizations towards venture creation. The purpose of developing this construct was to provide an appropriate framework to research on entrepreneurship (Naldi, Nordqvist, Sjöberg, \& Wiklund, 2007). According to Miller (1983), EO construct is comprised of three dimensions that are risk taking, proactiveness and innovativeness. Later on, Covin and Slevin (1988) defined the EO construct more comprehensively on the basis of Miller's work as "the entrepreneurial orientation of a firm is demonstrated by the extent to which the top managers are inclined to take business-related risks (the risk-taking dimension), to favour change and innovation in order to obtain a competitive advantage for their firm (the innovation dimension), and to compete aggressively with other firms (the proactiveness dimension)".

Two additional dimensions of EO construct namely competitive aggressiveness and autonomy were included by Lumpkin and Dess (1996). They were of the view that these five dimensions are required to define the EO construct in a comprehensive way. They defined EO as "the processes, practices, and decision-making activities that lead to new entry". This definition is different from the one provided by Covin and Slevin (1988), as this definition has taken into consideration the strategic decisions of the organization that stimulate the new entry.

There has been a rapid growth on research focusing the conceptualization of EO construct. These studies can be classified into two groups. Some of the studies have been measuring the effects of EO on performance of the organization (Lumpkin \& Dess, 2001; Hughes \& Morgan, 2007; Tang, Tang, Marino, \& Li, 2008; Moreno \& Casillas, 2008; Casillas, Moreno, \& Barbero, 2010; Frank, Kessler, \& Fink, 2010), while other studies have been focusing on indentifying the determinants of EO (Lee \& Peterson, 2001; Dickson, 2004; Kellermanns \& Eddleston, 2006; Casillas, Moreno, \& Barbero, 2011; Weismeier-Sammer, 2011; Cruz \& Nordqvist, 2012). However, regardless of this classification, all the studies have measured the EO construct either with three dimensions (Dickson, 2004; Kellermanns \& Eddleston, 2006; Tang et al., 2008; Casillas et al., 2010; Frank et al., 2010; Cruz \& Nordqvist, 2012) or five dimensions (Lee \& Peterson, 2001; Hughes \& Morgan, 2007; Li, Huang, $\&$ Tsai, 2009). The current study will measure the EO construct with five dimensions.

\subsection{Risk-Taking}

Risk taking refers to the propensity of the organization's top management to take bold decisions. These may include the decision like launching a new product, entering a new market, hiring more staff, and investing huge amount of resources in a risky venture (Rauch, Wiklund, Lumpkin, \& Frese, 2009). Risk taking is the willingness of a manager to commit significant to opportunities that have reasonable chance of costly failure (Lumpkin \& Dess, 1996). Some researchers have indicated that risk taking is the attribute of the manager. This ability reflects that the manager is capable enough to accept the challenges posed by environment and attempts to grab the new opportunities in the market (Hughes \& Morgan, 2007). Risk taking propensity of an organization is basically the result of opportunity seeking attitude. The management tends to get the benefit of market opportunities in pursuit of earning high returns (Lumpkin \& Dess, 1996; Tang et al., 2008; Rauch et al., 2009).

According to Brockhaus (1980), entrepreneurs take calculated but it is considered as higher risk by those businessmen who are not entrepreneurs. The entrepreneurs have more optimistic view about certain business activities and they exhibit much confidence to take the benefits of these opportunities as compared to non-entrepreneurs (Palich \& Bagby, 1995; Busenitz, 1999; Li et al., 2009; Alegre \& Chiva, 2013). Therefore, it is concluded that enterprenurs have different views regarding risk taking as comapred to the non-entrepreneurs (Chen \& Hsu, 2013). An entrepreneur sets the business patterns that exhibits the entrepreneurial characteristics of the firm and has the ability to make decision in the face of uncertainty that reflects risk, whereas, the non-entreprenuer is always hesitatant to make decision in an uncertain situation (Miller, 1983; Covin \& Slevin, 1988). 
Risk taking dimension of EO construct is very close to innovation and proactiveness (Chen \& Hsu, 2013). Proactiveness fosters the organization to get ready for grabbing the market opportunities. This characteristic carries risk taking behaviour that can be seen in form of introducing new products or services and entry into a new market (Tang et al., 2008). Risk taking approach of the organization may lead to creative and innovative ideas (Wagener, Gorgievski, \& Rijsdijk, 2010) thereby earning more profits for the organization in the long run (Wiklund \& Shepherd, 2005). However, too much focusing this approach may entails the probability of a negative linkage between the environment and business success (Rauch \& Frese, 2007). Moreover, large scale operations that involve a significant risk require continuous investment of resources and a vigilant risk management system. Otherwise the cost of failure may rise that may results in decline in the performance of organization (Chen \& Hsu, 2013).

\subsection{Proactiveness}

Proactiveness is the ability to take the initiative, especially at the opportune moment (Kwak et al., 2013). It refers to a forward looking perspective and a firm's tendency to "take initiative by anticipating and pursuing new opportunities and by participating in the emerging markets" (Lumpkin \& Dess, 1996). It refers to the propensity of organization towards "seeking new opportunities which may or may not be related to the present line of operations, introduction of new products and brands ahead of competition, strategically eliminating operations which are in the mature or declining stages of life cycle" (Venkatraman, 1989). The organizations with proactive behaviour have forward-looking attitude and ability to change the environment (Covin \& Slevin, 1989). These organizations continuously monitor their internal as well external environments and strive to become pioneer in the market by introducing new product lines and exploiting the market opportunities (Hughes \& Morgan, 2007). These firms strive to be the market leaders and not the followers. These firms are likely to get higher returns as compared to their competitors in the market because of early responsiveness to the market signals (Lumpkin \& Dess, 2001). Usually, this responsiveness becomes visible in shape of introducing new products and services in the market. Therefore, proactiveness dimension is closely linked to innovativeness (Lumpkin \& Dess, 1996).

According to (Vora \& Polley, 2012), firms characterized by proactiveness attempt to discover future opportunities, even these opportunities may be somewhat unrelated to current operations. They further described that these firms identify and exploit opportunities to meet demands, possibly through their own innovation. Covin and Slevin (1988) made a comparison of this characteristic with passive and reactive approach of a traditional and conservative firm. Similarly, Lumpkin and Dess (2001) explain that leadership characteristics of an organization emerge in the market as a result of proactive approach, because the organization challenges the environment with this approach. Entrepreneurs always remain ahead of their competitors in the market and thus the entrepreneurial firms are proactive (Chen \& Hsu, 2013).

A firm that follows the proactive approach in the market continuously seeks to bring improvements in its operations. This improvement requires continuous acquisition of knowledge that enables the firm to improve its operational efficiency and to sense the emerging opportunities in the market before its competitors (Dess \& Lumpkin, 2005). Proactive firm creates such an environment that is advantageous to it (Zahra \& Covin, 1995). Consequently, the firm occupies a prominent place in the market by getting the recognition of its brand ahead of its competitors and leads towards high profits (Dess \& Lumpkin, 2005). On the other hand, sometimes a highly proactive approach of a firm may results in the development of products that are not in line with the image of the firm (Richard et al., 2004). The firm may try to find out new markets and invest more resources. The existing market is often neglected in search of new markets. Moreover, the investment of resources to a particular product or market may increase the cost of the company. Therefore, a highly proactive approach may not be beneficial for the firm and may results in negative consequences to it (Chen \& Hsu, 2013).

Some researchers have serious apprehensions about the proactive behaviour of the organizations. They raise questions about the effectiveness of proactiveness. The possibility of the return that organization expect to earn by becoming pioneer in the market is doubtful. The uncertainty associated with the outcomes is exacerbated by the rapid changes in the technological environment. The competitive advantage, associated with the newness of products, cannot be sustained for a longer period of time because of the rapid innovations taking place in the markets (Zellweger, Kellermanns, Eddleston, \& Memili, 2012).

\subsection{Innovativeness}

Innovativeness refers to a general willingness to depart from proven practices or a tendency of a firm to engage in and support new ideas, novelty, experimentation, and creative processes that may result in new products, services, or technological processes (Lumpkin \& Dess, 1996). Innovativeness underpins creativity and willingness of experimentation in technological system for the development of new products through R \& D 
(Rauch et al., 2009). It is innovative approach of the firm that differentiates it from its competitors in the market and provides a unique positioning (Hughes \& Morgan, 2007). Innovativeness in fact implies open-mindedness that to what extent the organization has the tendency to deviate from the traditional ways of business. The employees involving in introducing new ways of accomplishment of tasks are appreciated and they are not punished for their mistakes made during this process. This open mindedness allows the employees to think beyond the sphere of their jobs that leads the organization towards creation of new knowledge (Wang, 2008).

Innovation implies the development of new products and services through innovative and contemporary processes (Dess \& Lumpkin, 2005; Wang, 2008; Zellweger et al., 2012). According to Lumpkin and Dess (2001), innovation can be defined as, ". . . creativity and experimentation in introducing new products/services, and novelty, technological leadership and R\&D in developing new processes". According to Covin and Miles (1999), the concept of entrepreneurship cannot be prevalent without existence of innovation in the organizational processes, products or services. The organization must exhibit such behaviours and perform such actions that are epitome of innovation. The innovation must exist regardless of the existence of any of the other dimension of EO.

The rapid changes in the markets and the behaviour of customers compelled the organizations to bring innovativeness in their products, services and processes (Arzubiaga, Iturralde, \& Maseda, 2012). According to Zellweger and Sieger (2010), innovation can be distributed into two distinct categories, i.e. internal and external innovation. Internal innovation focuses on innovative improvements and value creation in the organization, whereas, external innovation results in the development of new products or services or processes. Innovativeness can lead the organization towards competitive advantage because the innovative competencies are acutely grown within organization and it is difficult to imitate these competencies (Barney, 1991). The organizations following innovativeness are fertile in skills and knowledge on the basis of which they flourish to develop core competencies that help them to replenish their operations and improve the performance in financial terms (Zahra \& Garvis, 2000). In this way, innovation can be rightly taken as the main predictor of the growth of a firm (Brüderl \& Preisendörfer, 2000).

The organizations following innovativeness continuously strive to develop new products that in turn increase their performance (Zahra \& Garvis, 2000). However, drastic innovations may result in such products that reduce the possibility of purchasing them by customers. Customers need to change their habits in order to purchase the innovative products. This may disturb their existing purchasing patterns. Therefore, the possibility of purchasing these innovative products may reduced significantly (Szymanski, Kroff, \& Troy, 2007). Therefore, the organization should invest more resources in developing an effective system of communication with customers (Tang et al., 2008). Customers should be made aware of the innovative features of the products and that how these features can be beneficial for them as well. Thus, organizations have to invest the resources not only in the new technologies that will replace the existing ones but also in promotional means so that the customers can be attracted and they may take actions to purchase them. This will increase the cost of organization that is most likely to reduce the profitability (Chen \& Hsu, 2013).

\subsection{Competitive Aggressiveness}

The desire of an organization to challenge the capabilities of its rivals and formulating the aggressive strategies to outperform them in the market is referred to competitive aggressiveness (Lumpkin \& Dess, 1996). This implies that all these strategies should be devised with the objective to sustain the firm market positioning against the efforts exerted by rival. These strategies are also devised to adjust the firm in response to the changing trends of the marketplace that may put the survival of organization in danger (Short, Broberg, Cogliser, \& Brigham, 2010). Moreover, competitive aggressiveness shows the organizational desire to use original and new means rather than traditional means of competing in the market (Lumpkin \& Dess, 1996).

Competitive aggressiveness can surface in a number of forms in an organization. It may reflect in the form of price competitions, introducing innovative products in the market with superior features as compared to competitors' products, haunting the rivals in the market, giving eccentric surprises to the market and exploiting the information. All these strategies and tactics are aimed at increasing the market share of the firm and attracting more customers by targeting the weaknesses of competitors. It is also aimed at undermining the ability of the competitors to compete in the market (Hughes \& Morgan, 2007). Competitive aggressiveness has close similarity to the proactiveness dimension of the EO construct. Sometimes the difference between the two dimensions is blurred. Proactiveness is referred to the ability of the firm to anticipate the upcoming changes in the market and customer behaviour on the basis of which firms take prompt actions to respond to the challenges posed by environment. The firms decide either to develop and introduce new products and services or to enter 
into a new market (Lumpkin \& Dess, 2001). These products and services are introduced in the market before competitors. The competitive aggressiveness concept also fosters the organization to be pioneer in the market and remain ahead of their competitors (Arzubiaga et al., 2012).

\subsection{Autonomy}

Autonomy refers to the independence that an individual enjoys in presenting an idea or taking and implementing a decision. This independence also includes the follow up of a vision till its accomplishment (Lumpkin \& Dess, 1996). It is the ability and willingness of entrepreneur to independently follow the market opportunities. The autonomy plays an important role in promptly identifying the emerging opportunities in the market and efficiently utilizing the organizational resources to grab these opportunities. This autonomy helps the firm in creating new ventures and bringing improvement in business processes (Kanter, 1983). Autonomy can be said to be a prerequisite for bringing innovation that acts as a stimuli for the start-up of an entrepreneurial venture. Also it increases the organizational effectiveness and improves the profitability of the firm (Burgelman, 1984).

Autonomy exhibits the trust of the management on the abilities of the employees and encourages them to participate in the long term growth of the organization by using their capabilities beyond the established practices within the organization. Autonomy is an idea that is closely linked to flexibility (Arzubiaga et al., 2012). Flexibility allows the firm to respond promptly to the environmental changes. The responsiveness of the organization to the signal generated by the market increases, if firm has the required level of flexibility. Conversely, the coordination at all organizational levels is required to increase the effectiveness of responsiveness resulting from autonomy and flexibility. Thus, autonomy proves to be a locomotive of the change process and entrepreneurial activity in the organization (Hughes \& Morgan, 2007). However, financial constraints are more likely to influence the organization by restricting the scope of its entrepreneurial activities if organization is too much obsessed with the participatory process of decision making and remains busy in developing consensus at all organizational levels (Covin et al., 2006).

\section{Discussion}

Entrepreneurship and entrepreneurial orientation are considered as important drivers of SMEs growth (Eggers, Kraus, \& Hughes, 2013). Entrepreneurship at a firm level stems from the entrepreneurial venture's orientation towards identifying market opportunities that competitors have not yet recognized or that are under-exploited, and creating a unique set of resources to exploit them (Davidsson, Delmar, \& Wiklund, 2002; Hitt, Ireland, Camp, \& Sexton, 2002; Eggers et al., 2013). Entrepreneurship is the act of creation of organization or renewal that occurs within or outside of the organization (Sharma \& Chrisman, 1999), While, entrepreneurial orientation explains that how to put in practice the entrepreneurship (Ireland \& Webb, 2007). EO is a managerial oriented attitude toward the strategy making processes which provides a basis for entrepreneurial decision and actions to organization (Lumpkin \& Dess, 1996; Richard et al., 2004; Alegre \& Chiva, 2013). Several studies have revealed a positive impact of entrepreneurial orientation on performance (Keh, Nguyen, \& $\mathrm{Ng}$, 2007; Tang et al., 2008; Rauch et al., 2009; Su, Xie, \& Li, 2011; Tang \& Tang, 2012; Alegre \& Chiva, 2013; Hakala, 2013). Entrepreneurial orientation plays an important role in bringing organizational success and better performance (Huang, Wang, Chen, \& Yien, 2011; Brettel \& Rotenberger, 2013). Literature reveals that innovation facilitates growth by offering new products with high profit potential and enhances the overall market value of entrepreneurial firm (Cho \& Pucik, 2005; Kuratko, 2009; Wiklund Patzelt, \& Shepherd, 2009; Kreiser, Marino, Kuratko, \& Weaver, 2013). Innovativeness also enhances the abilities of SMEs to cope up with the changing market environment by offering innovative products (Ireland, Covin, \& Kuratko, 2009; Jabeen et al., 2013). Proactive firms have the ability to exploit the available opportunities by scanning the environment for the information that is useful to be utalized to satisfy the underserved markets (Hughes and Morgan, 2007; Smith \& Cao, 2007; Hakala, 2013; Kwak, Jaju, Puzakova, \& Rocereto, 2013). Risk oriented firm have the propensity to search for new resources (Lumpkin \& Dess, 1996; Hughes \& Morgan, 2007; Alegre \& Chiva, 2013). Thus:

Preposition 1: Entrepreneurial Orientation (risk-taking) has positive effect on the performance of SMEs.

Preposition 2: Entrepreneurial Orientation (innovativeness) has positive effect on the performance of SMEs.

Preposition 3: Entrepreneurial Orientation (proactiveness) has positive effect on the performance of SMEs.

Preposition 4: Entrepreneurial Orientation (competitive aggressiveness) has positive effect on the performance of SMEs.

Preposition 5: Entrepreneurial Orientation (autonomy) has positive effect on the performance of SMEs.

This study investigates the dimensions of entrepreneurial orientation and the way they are related to the performance of SMEs. Several studies have examined the effect of entrepreneurial orientation on organizational 
performance (Deshpande \& Webster, 1989; Deshpande, Farley, \& Webster, 1993; Pelham \& Wilson, 1996). However, this relationship has been checked mostly in large scale organization (Zahra, 1996; Huang et al., 2011; Hakala, 2013). Less attention has been paid to research focusing on EO and firm performance relationship (Covin \& Slevin, 1991; Zahra, 1996; Salavou \& Liokas, 2003; Wiklund \& Shepherd, 2005, Huang et al., 2011). This relationship in the context of SMEs needs to be explored.

EO has become a crucial construct for the survival, growth and superior performance for SMEs of the modern era (Rauch et al., 2009; Hakala, 2013). EO facilitate the small and new ventures in achieving growth, performing better and ensuring the long term success (Lussier, 1995; Lumpkin \& Dess, 2001; Wiklund \& Shepherd, 2005; Zulkifli \& Rosli, 2013). The researcher found that the proactiveness dimension of EO hold positive relationship with sales level while innovativeness positively effects the sales growth, sales level and gross profit (Kreiser, Marino, \& Weaver, 2002). According to Sascha et al., (2011) the behavior of proactive firm positively contributes to SME performance during the time of economic crisis. Proactive behavior enables the SMEs to discover and exploit environmental opportunities before their competitors (Smith \& Cao, 2007) and to place them in an advantageous strategic position (Lumpkin \& Dess, 2001).

SMEs are facing an increasingly pressure from the marketplace (Zulkifli \& Rosli, 2013). The SMEs can ensure their survival if they do not embrace the entrepreneurial orientation in true sense (Rauch et al., 2009; Kwak et al., 2013). Thus, entrepreneurial activities among SMEs has become even more crucial in achieving the firm sustainable competitive advantage (Wiklund \& Shepherd, 2003) and they are encouraged to implement an entrepreneurial strategic mindset in order to recognize the threats and grab the opportunities to ensure the firm's will continue to sustain the future (Krueger, 2000; Kraus et al., 2012).

\section{Conclusions}

This study provides thorough literature review on the relationship of entrepreneurial orientation and performance of SMEs. Five propositions were developed on the dimensions of entrepreneurial orientation and performance of SMEs. The current study concludes that entrepreneurial orientation EO is positively linked to growth, competitive advantage and superior performance of SMEs. To compete in the cut throat competition at domestic and global levels, SMEs must review their strategies and adapt them according to the changing and dynamic environment. Also, SMEs should constantly seek new ways to exercise flexibility and improve their abilities to become innovative and more competitive in order to ensure growth and superior performance.

\section{References}

Alegre, J., \& Chiva, R. (2013). Linking Entrepreneurial Orientation and Firm Performance: The Role of Organizational Learning Capability and Innovation Performance. Journal of Small Business Management. http://dx.doi.org/10.1111/jsbm.12005

Arzubiaga, U., Iturralde, T., \& Maseda, A. (2012). The Entrepreneurial Orientation Construct, Dimensions and Measurement Scales in the Case of Family Firm: A Literature Review and some Considerations. European Journal of Social Sciences, 33(3), 437-454.

Baird, I. S., \& Thomas, H. (1985). Toward a contingency model of strategic risk taking. Academy of Management Review, 10(2), 230-243. http://dx.doi.org/10.5465/AMR.1985.4278108

Barney, J. (1991). Firm resources and sustained competitive advantage. Journal of management, 17(1), 99-120. http://dx.doi.org/10.1177/014920639101700108

Birkinshaw, J. (1997). Entrepreneurship in multinational corporations: The characteristics of subsidiary initiatives. Strategic management journal, 18(3), 207-229. http://dx.doi.org/10.1002/(SICI)1097-0266

Brettel, M., \& Rottenberger, J. D. (2013). Examining the Link between Entrepreneurial Orientation and Learning Processes in Small and Medium Sized Enterprises. Journal of Small Business Management, 1-20. http://dx.doi.org/10.1111/jsbm.12002

Brockhaus, R. H. (1980). Risk taking propensity of entrepreneurs. Academy of Management Journal, 23(3), 509-520. http://dx.doi.org/10.2307/255515

Brüderl, J., \& Preisendörfer, P. (2000). Fast-growing businesses: Empirical evidence from a German study. International journal of sociology, 45-70.

Burgelman, R. A. (1984). Designs for corporate entrepreneurship in established firms. Graduate School of Business, Stanford University.

Busenitz, L. W. (1999). Entrepreneurial Risk and Strategic Decision Making It'sa Matter of Perspective. The 
Journal of Applied Behavioral Science, 35(3), 325-340. http://dx.doi.org/10.1177/0021886399353005

Casillas, J. C., Moreno, A. M., \& Barbero, J. L. (2010). A configurational approach of the relationship between entrepreneurial orientation and growth of family firms. Family Business Review, 23(1), 27-44. http://dx.doi.org/10.1177/0894486509345159

Casillas, J. C., Moreno, A. M., \& Barbero, J. L. (2011). Entrepreneurial orientation of family firms: Family and environmental dimensions. Journal of Family Business Strategy, 2(2), 90-100. http://dx.doi.org/10.1016/j.jfbs.2011.03.002

Chattopadhyay, P., Glick, W. H., \& Huber, G. P. (2001). Organizational actions in response to threats and opportunities. Academy of Management Journal, 44(5), 937-955. http://dx.doi.org/10.2307/3069439

Chen, H. L., \& Hsu, C.-H. (2013). Entrepreneurial orientation and firm performance in non-profit service organizations: contingent effect of market orientation. The Service Industries Journal, 33(5), 445-466. http://dx.doi.org/10.1080/02642069.2011.622372

Cho, H. J., \& Pucik, V. (2005). Relationship between innovativeness, quality, growth, profitability, and market value. Strategic management journal, 26(6), 555-575.

Covin, J., \& Slevin, D. (1991). A Conceptual Model Of Entrepreneurship As Firm Behaviour Entrepreneurship Theory And Practice, 16(1), 7-25. http://dx.doi.org/10.1002/smj.461

Covin, J. G., \& Miles, M. P. (1999). Corporate Entrepreneurship and the Pursuit of Competitive Advantage. Entrepreneurship Theory and Practice, 23(3), 47-63.

Covin, J. G., Green, K. M., \& Slevin, D. P. (2006). Strategic process effects on the entrepreneurial orientation-sales growth rate relationship. Entrepreneurship theory and practice, 30(1), 57-81. http://dx.doi.org/10.1111/j.1540-6520.2006.00110.x

Covin, J. G., \& Slevin, D. P. (1988). The influence of organization structure on the utility of an entrepreneurial top management style. Journal of Management Studies, 25(3), 217-234. http://dx.doi.org/10.1111/ j.1467-6486.1988.tb00033.x

Covin, J. G., \& Slevin, D. P. (1989). Strategic management of small firms in hostile and benign environments. Strategic management journal, 10(1), 75-87. http://dx.doi.org/10.1002/smj.4250100107

Cruz, C., \& Nordqvist, M. (2012). Entrepreneurial orientation in family firms: a generational perspective. Small Business Economics, 38(1), 33-49. http://dx.doi.org/10.1007/s11187-010-9265-8

Davidsson, P., Delmar, F., \& Wiklund, J. (2002). Entrepreneurship as growth: growth as entrepreneurship. In M. A. Hitt, R. D. Ireland, S. M. Camp, \& D. L. Sexton (Eds.), Strategic Entrepreneurship: Creating a New Mindset, Blackwell, Oxford (pp. 328-340).

Deshpandé, R., Farley, J. U., \& Webster, F. E. Jr. (1993). Corporate culture, customer orientation, and innovativeness in Japanese firms: a quadrad analysis. The Journal of Marketing, 23-37.

Deshpande, R., \& Webster, F. E. Jr. (1989). Organizational culture and marketing: defining the research agenda. The Journal of Marketing, 3-15.

Dess, G. G., \& Lumpkin, G. T. (2005). The role of entrepreneurial orientation in stimulating effective corporate entrepreneurship. The Academy of Management Executive, 19(1), 147-156. http://dx.doi.org/10.5465/ AME.2005.15841975

Dickson, P. H. (2004). Entrepreneurial orientation: The role of institutional environment and firm attributes in shaping innovation and proactiveness. pat, 404, 894-4372.

Eggers, F., Kraus, S., Hughes, M., Laraway, S., \& Snycerski, S. (2013). Implications of customer and entrepreneurial orientations for SME growth. Management Decision, 51(3), 524-546. http://dx.doi.org/ $10.1108 / 00251741311309643$

Frank, H., Kessler, A., \& Fink, M. (2010). Entrepreneurial orientation and business performance-a replication study. Schmalenbach Business Review, 62, 175-198.

Hakala, H. (2013). Entrepreneurial and learning orientation: effects on growth and profitability in the software sector. Baltic Journal of Management, 8(1), 102-118. http://dx.doi.org/10.1108/17465261311291687

Hitt, M. A., Ireland, R. D., Camp, S. M., \& Sexton, D. L. (2002). Strategic entrepreneurship: Integrating entrepreneurial and strategic management perspectives. Strategic entrepreneurship: Creating a new mindset, $1-16$. 
Huang, K.-P., Wang, K. Y., Chen, K.-H., \& Yien, J.-M. (2011). Revealing the Effects of Entrepreneurial Orientation on Firm Performance: A Conceptual Approach. Journal of Applied Sciences, 11, 3049-3052.

Hughes, M., \& Morgan, R. E. (2007). Deconstructing the relationship between entrepreneurial orientation and business performance at the embryonic stage of firm growth. Industrial Marketing Management, 36(5), 651-661. http://dx.doi.org/10.1016/j.indmarman.2006.04.003

Ireland, R. D., Covin, J. G., \& Kuratko, D. F. (2009). Conceptualizing corporate entrepreneurship strategy. Entrepreneurship theory and practice, 33(1), 19-46. http://dx.doi.org/10.1111/j.1540-6520.2008.00279.x

Ireland, R. D., \& Webb, J. W. (2007). A cross-disciplinary exploration of entrepreneurship research. Journal of management, 33(6), 891-927. http://dx.doi.org/10.1177/0149206307307643

Jabeen, R., Alekam, J. M. E., Aldaoud, K. A. M., Mat, N. K. N., Zureigat, B. N. I., \& Nahi, A. K. (2013). Antecedents of Firm's Performance. Empirical Evidence from Yemeni Sme's. American Journal of Economics, 3(1), 18-22. http://dx.doi.org/10.5923/j.economics.20130301.04

Kanter, R. M. (1983). The change masters: Innovation and entrepreneurship in the American corporation. New York: Simon and Schuster.

Keh, H. T., Nguyen, T. T. M., \& Ng, H. P. (2007). The effects of entrepreneurial orientation and marketing information on the performance of SMEs. Journal of business venturing, 22(4), 592-611. http://dx.doi.org/ 10.1016/j.jbusvent.2006.05.003

Kellermanns, F. W., \& Eddleston, K. A. (2006). Corporate entrepreneurship in family firms: A family perspective. Entrepreneurship theory and practice, 30(6), 809-830. http://dx.doi.org/10.1111/j.1540-6520.2006.00153.x

Kraus, S., Rigtering, J. C., Hughes, M., \& Hosman, V. (2012). Entrepreneurial orientation and the business performance of SMEs: a quantitative study from the Netherlands. Review of Managerial Science, 6(2), 161-182. http://dx.doi.org/10.1007/s11846-011-0062-9

Kreiser, P. M., Marino, L. D., Kuratko, D. F., \& Weaver, K. M. (2013). Disaggregating entrepreneurial orientation: the non-linear impact of innovativeness, proactiveness and risk-taking on SME performance. Small Business Economics, 40(2), 273-291. http://dx.doi.org/10.1007/s11187-012-9460-x

Kreiser, P. M., Marino, L. D., \& Weaver, K. M. (2002). Assessing the psychometric properties of the entrepreneurial orientation scale: A multi-country analysis. Entrepreneurship Theory and Practice, 26(4). http://dx.doi.org/71-94.1042-2587-02-264

Krueger, N. (2000). The cognitive infrastructure of opportunity emergence. Entrepreneurship Theory Practice, 24(3), 5-23.

Kuratko, D. F. (2009). The entrepreneurial imperative of the $21^{\text {st }}$ century. Business Horizons, 52(5), 421-428.

Kwak, H., Jaju, A., Puzakova, M., \& Rocereto, J. F. (2013). The Connubial Relationship Between Market Orientation and Entrepreneurial Orientation. The Journal of Marketing Theory and Practice, 21(2), 141-162. http://dx.doi.org/10.2753/MTP1069-6679210202

Lee, S. M., \& Peterson, S. J. (2001). Culture, entrepreneurial orientation, and global competitiveness. Journal of world business, 35(4), 401-416. http://dx.doi.org/10.1016/S1090-9516(00)00045-6

Li, Y.-H., Huang, J.-W., \& Tsai, M.-T. (2009). Entrepreneurial orientation and firm performance: The role of knowledge creation process. Industrial Marketing Management, 38(4), 440-449. http://dx.doi.org/10.1016/ j.indmarman.2008.02.004

Lin, Z., \& Carley, K. M. (2001). Organizational design and adaptation in response to crises: theory and practice. Academy of Management Conference Best Paper Proceedings 2001, 1-7.

Lumpkin, G. T., \& Dess, G. G. (1996). Clarifying the entrepreneurial orientation construct and linking it to performance. Academy of Management Review, 21(1), 135-172. http://dx.doi.org/10.5465/AMR.1996. 9602161568

Lumpkin, G. T., \& Dess, G. G. (2001). Linking two dimensions of entrepreneurial orientation to firm performance: The moderating role of environment and industry life cycle. Journal of business venturing, 16(5), 429-451. http://dx.doi.org/10.1016/S0883-9026(00)00048-3

Lussier, R. N. (1995). A nonfinancial business success versus failure prediction model for young firms. Journal of Small Business Management, 33(1), 8-20.

Miller, D. (1983). The correlates of entrepreneurship in three types of firms. Management science, 29(7), 
770-791. http://dx.doi.org/10.1287/mnsc.29.7.770

Moreno, A. M., \& Casillas, J. C. (2008). Entrepreneurial orientation and growth of SMEs: A causal model. Entrepreneurship theory and practice, 32(3), 507-528. http://dx.doi.org/10.1111/j.1540-6520.2008.00238.x

Morris, M. H., Kuratko, D. F., \& Covin, J. G. (2008). Corporate entrepreneurship and innovation (2nd ed.). Mason: Thomson Higher Education

Naldi, L., Nordqvist, M., Sjöberg, K., \& Wiklund, J. (2007). Entrepreneurial orientation, risk taking, and performance in family firms. Family Business Review, 20(1), 33-47. http://dx.doi.org/10.1111/j.17416248.2007.00082.x

Palich, L. E., \& Ray Bagby, D. (1995). Using cognitive theory to explain entrepreneurial risk-taking: Challenging conventional wisdom. Journal of business venturing, 10(6), 425-438. http://dx.doi.org/ 10.1016/0883-9026(95)00082-J

Pelham, A. M., \& Wilson, D. T. (1996). A longitudinal study of the impact of market structure, firm structure, strategy, and market orientation culture on dimensions of small-firm performance. Journal of the academy of Marketing Science, 24(1), 27-43. http://dx.doi.org/10.1177/009207039602400103

Rauch, A., \& Frese, M. (2007). Let's put the person back into entrepreneurship research: A meta-analysis on the relationship between business owners' personality traits, business creation, and success. European Journal of Work and Organizational Psychology, 16(4), 353-385. http://dx.doi.org/10.1080/13594320701595438

Rauch, A., Wiklund, J., Lumpkin, G. T., \& Frese, M. (2009). Entrepreneurial orientation and business performance: An assessment of past research and suggestions for the future. Entrepreneurship theory and practice, 33(3), 761-787. http://dx.doi.org/10.1111/j.1540-6520.2009.00308.x

Richard, O. C., Barnett, T., Dwyer, S., \& Chadwick, K. (2004). Cultural diversity in management, firm performance, and the moderating role of entrepreneurial orientation dimensions. Academy of Management Journal, 47(2), 255-266. http://dx.doi.org/10.2307/20159576

Salavou, H., \& Lioukas, S. (2003). Radical product innovations in SMEs: the dominance of entrepreneurial orientation. Creativity and Innovation Management, 12(2), 94-108. http://dx.doi.org/10.1111/14678691.00272

Sascha, K. J., P, R. C., Hughes, M., \& Hosman, V. (2011). Entrepreneurial Orientation And The Business Performance of Smes: A Quantitative Study From The Netherlands. Rev Manag Sci, http://dx.doi.org/10.1007/s11846-011-0062-9

Sexton, D. L., \& K., J. D. (1992). State of the Art of Entrepreneurship. PWS-Kent, Boston, MA.

Sharma, P., \& Chrisman, J. J. (1999). Toward a Reconciliation of the Definitional Issues in the Field of Corporate Entrepreneurship. Entrepreneurship Theory and Practice, 23, 11-27.

Short, J. C., Broberg, J. C., Cogliser, C. C., \& Brigham, K. H. (2010). Construct Validation Using Computer-Aided Text Analysis (CATA) An Illustration Using Entrepreneurial Orientation. Organizational Research Methods, 13(2), 320-347.

Smith, K. G., \& Cao, Q. (2007). An entrepreneurial perspective on the firm-environment relationship. Strategic Entrepreneurship Journal, 1(3-4), 329-344. http://dx.doi.org/10.1002/sej.25

$\mathrm{Su}, \mathrm{Z}$., Xie, E., \& Li, Y. (2011). Entrepreneurial orientation and firm performance in new ventures and established firms. Journal of Small Business Management, 49(4), 558-577. http://dx.doi.org/10.1111/j.1540627X.2011.00336.X

Szymanski, D. M., Kroff, M. W., \& Troy, L. C. (2007). Innovativeness and new product success: insights from the cumulative evidence. Journal of the academy of Marketing Science, 35(1), 35-52. http://dx.doi.org/10.1007/s11747-006-0014-0

Tang, J., Tang, Z., Marino, L. D., Zhang, Y., \& Li, Q. (2008). Exploring an Inverted U-Shape Relationship between Entrepreneurial Orientation and Performance in Chinese Ventures. Entrepreneurship theory and practice, 32(1), 219-239. http://dx.doi.org/10.1111/j.1540-6520.2007.00223.x

Tang, Z., \& Tang, J. (2012). Entrepreneurial orientation and SME performance in China's changing environment: The moderating effects of strategies. Asia Pacific Journal of Management, 29(2), 409-431. http://dx.doi.org/10.1007/s10490-010-9200-1

Venkatraman, N. (1989). Strategic orientation of business enterprises: the construct, dimensionality, and 
measurement. Management science, 35(8), 942-962.

Vora, D., Vora, J., \& Polley, D. (2012). Applying entrepreneurial orientation to a medium sized firm. International Journal of Entrepreneurial Behaviour \& Research, 18(3), 352-379. http://dx.doi.org/10.1108/ 13552551211227738

Wagener, S., Gorgievski, M., \& Rijsdijk, S. (2010). Businessman or host? Individual differences between entrepreneurs and small business owners in the hospitality industry. The Service Industries Journal, 30(9), 1513-1527. http://dx.doi.org/10.1080/02642060802624324

Wang, C. L. (2008). Entrepreneurial orientation, learning orientation, and firm performance. Entrepreneurship theory and practice, 32(4), 635-657. http://dx.doi.org/10.1111/j.1540-6520.2008.00246.x

Weismeier-Sammer, D. (2011). Entrepreneurial behavior in family firms: A replication study. Journal of Family Business Strategy, 2(3), 128-138. http://dx.doi.org/10.1016/j.jfbs.2011.07.003

Wiklund, J., Patzelt, H., \& Shepherd, D. A. (2009). Building an integrative model of small business growth. Small Business Economics, 32(4), 351-374.

Wiklund, J., \& Shepherd, D. (2003). Knowledge-based resources, entrepreneurial orientation, and the performance of small and medium-sized businesses. Strategic management journal, 24(13), 1307-1314. http://dx.doi.org/10.1002/smj.360

Wiklund, J., \& Shepherd, D. (2005). Entrepreneurial orientation and small business performance: a configurational approach. Journal of business venturing, 20(1), 71-91. http://dx.doi.org/10.1016/j.jbusvent. 2004.01.001

Williams, C., Round, J., \& Rodgers, P. (2010). Explaining the off-the-book enterprise culture of Ukraine: reluctant or willing entrepreneurship? International Journal of Entrepreneurship \& Small Business, 10(2), 165-180.

Zahra, S. A. (1996). Technology strategy and new venture performance: a study of corporate-sponsored and independent biotechnology ventures. Journal of business venturing, 11(4), 289-321. http://dx.doi.org/ 10.1016/0883-9026(95)00128-X

Zahra, S. A., \& Covin, J. G. (1995). Contextual influences on the corporate entrepreneurship-performance relationship: A longitudinal analysis. Journal of business venturing, 10(1), 43-58. http://dx.doi.org/10.1016/ 0883-9026(94)00004-E

Zahra, S. A., \& Garvis, D. M. (2000). International corporate entrepreneurship and firm performance: The moderating effect of international environmental hostility. Journal of business venturing, 15(5), 469-492. http://dx.doi.org/10.1016/S0883-9026(99)00036-1

Zellweger, T., \& Sieger, P. (2012). Entrepreneurial orientation in long-lived family firms. Small Business Economics, 38(1), 67-84. http://dx.doi.org/10.1007/s11187-010-9267-6

Zellweger, T. M., Kellermanns, F. W., Eddleston, K. A., \& Memili, E. (2012). Building a family firm image: How family firms capitalize on their family ties. Journal of Family Business Strategy.

Zulkifli, R. M., \& Rosli, M. M. (2013). Entrepreneurial Orientation and Business Success of Malay Entrepreneurs: Religiosity as Moderator. International Journal of Humanities and Social Science, 3(10), 264-275.

\section{Copyrights}

Copyright for this article is retained by the author(s), with first publication rights granted to the journal.

This is an open-access article distributed under the terms and conditions of the Creative Commons Attribution license (http://creativecommons.org/licenses/by/3.0/). 